\title{
The coseismic ground deformations of the 1997 Umbria-Marche earthquakes: a lesson for the development of new GPS networks
}

\author{
Marco Anzidei ( $\left.{ }^{1}\right)$, Paolo Baldi $\left({ }^{2}\right)$ and Enrico Serpelloni $\left({ }^{1}\right)$ \\ (') Istituto Nazionale di Geofisica e Vulcanologia, Centro Nazionale Terremoti, Roma \\ $\left.{ }^{(}{ }^{2}\right)$ Università degli Studi di Bologna, Dipartimento di Fisica, Settore Geofisica, Bologna
}

\begin{abstract}
After the occurrence of the two main shocks Mw=5.7 (00.33 GMT) and Mw=6.0 (09:40 GMT) on September 26, 1997, which caused severe damages and ground cracks in a wide area of the Umbria Marche region, the Istituto Nazionale di Geofisica in cooperation with the Istituto Geografico Militare Italiano set out to detect the coseismic ground deformation and reoccupied the available geodetic monuments placed across the epicentral area, belonging to the first order Italian GPS network IGM95 and to the Tyrgeonet network.

The comparison between the pre and post-earthquakes coordinate set, the latter obtained from the surveys performed in the early days of October 1997 in the Umbria Marche earthquake area, showed maximum displacements values at the closest stations to the epicentres, up to $14.0 \pm 1.8$ and $24.0 \pm 3.0 \mathrm{~cm}$ in the horizontal and vertical components, respectively. The availability of the IGM95 stations allowed geodetic data to be translated into relevant geophysical results. For the first time in Italy, the evaluation of post-earthquake coordinates at 13 vertices provided the estimation of a significant deformation field associated with a seismic sequence.

Unfortunately, the same actions could not be applied to the October 14, 1997, Mw=5.6 Sellano earthquake, whose epicentre was located a few tens of km south of the previous ones, due to a lack of available geodetic vertices of Tyrgeonet and IGM95 networks in the surroundings of the epicentral zone. This fact, which prevented the estimation of coseismic deformation and seismic source modelling for this earthquake, clarified the need to set up tailor made GPS networks devoted to geophysical applications, able to capture a possible coseismic signal, but also interseismic and post-seismic signals, at the surface of the Earth's crust at the scale of the expected magnitudes and fault length. Here we show and discuss the development of the Discrete GPS and Continuous GPS (CGPS) networks in the Italian region started since the early 1990s, which greatly increased after the 1997 Umbria Marche earthquakes, and the insights gained from this action which can be also integrated as Global Observing Strategy to monitor our Environment from Earth and Space.
\end{abstract}

Key words GPS - IGM95 - Umbria-Marche earthquakes

\section{Introduction}

The Italian peninsula is among the most active seismic areas of the Mediterranean basin and

Mailing address: Dr. Marco Anzidei, Istituto Nazionale di Geofisica e Vulcanologia, Centro Nazionale Terremoti, Via di Vigna Murata 605, 00143 Roma, Italy; e-mail: anzidei@ingv.it its tectonic setting results from the collision between the African/Arabian and Eurasian plates (Dewey et al., 1989; Faccenna et al. 2004). The kinematics of this region has been predicted since 1994 with a NW-SE converging motion at about $7 \mathrm{~mm} / \mathrm{yr}$, from the NUVEL-1A plate motion model (De Mets et al., 1994). Recent analysis of GPS and seismic data (D'Agostino and Selvaggi, 2004; Serpelloni et al., 2005; Battaglia et al., 2004; Serpelloni et al., 2007 and references therein) estimated new converging velocities and complex deformation patterns along the AfricaEurasia plate boundary. The distribution of in- 
strumental seismicity depicts the high crustal fragmentation of the area and provides a picture of the plate boundary mosaic with tectonic units developed during the subduction and collision of the Alpine and Apennine belts (Dercourt et al., 1993; Malinverno and Ryan, 1986; Patacca et al.,1990; Chiarabba et al., 2005). From seismic tomography it appears that the initially continuous Apennines subduction has been segmented into different arcs, due to the nature of the lithospheric subducting material (Piromallo and Morelli, 2003)

The Apennines suffer from the complex Mediterranean framework and are largely affected by extension oriented perpendicular to the chain axis (Anderson and Jackson 1987; Westaway 1990; Pondrelli et al. 1995; Selvaggi 1998; Vannucci et al., 2004), in agreement with the distribution of historical seismicity and other geological/geophysical observations (Valensise and Pantosti 2001a), which suggest the presence of active normal faults striking about parallel to the Apenninic chain (Valensise and Pantosti 2001b). Seismological data and recent geodetic studies reveal that the Apennines are undergoing a NE-trending extension, with seismic deformation rates higher in the southern Apennines (Anderson and Jackson, 1987; Westaway, 1990; Pondrelli et al., 2002; Hunstad et al., 2003; Serpelloni et al., 2005; Anzidei et al., 2005).

The extensional behaviour of the area, which was estimated only from seismic data at the time of the Umbria-Marche earthquakes (Selvaggi, 1998 and reference therein), has been revealed through the analysis of repeated GPS data obtained from the reoccupation of the discrete networks or through the available CGPS stations only in recent times. As a consequence, geodetic estimates of rates of crustal extension across the Apennines were still unknown in September 1997 (D'Agostino et al. 2001; Serpelloni et al. 2001; Hunstad et al. 2003; Anzidei et al., 2005; Serpelloni et al., 2005; Serpelloni et al., 2007). In the northern Apennines, earthquake focal mechanisms show that compression is active in the external sector of the arc (Montone and Mariucci 1999), where the few deep earthquakes have been interpreted as due to remnant subduction processes (Selvaggi and Amato 1992).

\section{The Umbria Marche seismic sequence of September-October 1997}

The 1997 Umbria-Marche seismic sequence, which caused severe damage and ground cracks in a wide area of the Umbria Marche region (Tosi et al., 1999), started on September 3 with a ML 4.7 foreshock followed by a large and diffuse microseismicity, in an area of the Apennines which was previously struck by a long seismic sequence during year 1703 (Boschi et al., 1995). On September 26, two moderate magnitude earthquakes occurred at 00:33 $(\mathrm{Mw}=5.7)$ and 09:40 GMT $(\mathrm{Mw}=$ 6.0) near the village of Colfiorito and on October 14 a third mainshock $(\mathrm{Mw}=5.6)$ took place $15 \mathrm{~km}$ to the SE, close to Sellano village. The whole seismic sequence consisted of six main earthquakes with magnitudes $>5.0$ that occurred in the following months on normal faults oriented NW-SE (Amato et al., 1998; Ekström et al., 1998). The spatial distribution of aftershocks (Amato et al., 1998; Cattaneo et al., 2000, and Deschamps et al., 2000) stretched $\sim 50 \mathrm{~km}$ along the Apennines seismogenic belt. Focal mechanisms resulting from CMT solutions show normal faulting on shallow low-angle faults (Ekström et al., 1998; Pino and Mazza, 2000). The three largest earthquakes ruptured normal faults dipping $40^{\circ}-45^{\circ}$ to the SW, with geometries well constrained by seismological data (Amato et al., 1998; Deschamps et al., 2000; Cattaneo et al., 2000; Ekström et al., 1998; Capuano et al., 2000). Moreover, three additional earthquakes of magnitude larger than 5.0 occurred close to the three largest shocks and showed similar fault plane solutions.

\section{The GPS networks in Italy at 1997: limits during the Umbria-Marche earthquakes}

During the occurrence of the UmbriaMarche earthquakes, two GPS national networks were available in Italy: the Tyrrhenian Geodetic Network (TyrGeoNet) (fig.1a) and the IGM95 (fig.1b). Both these networks consist of benchmarks established on reinforced concrete pillars, anchored in the bedrock or on stable 
buildings, planned to be measured during repeated geodetic campaigns. The former was established in 1990-1992 in the Mediterranean region by the Istituto Nazionale di Geofisica and the University of Bologna in cooperation with a group of Italian and foreign Institutions, with the aim of measuring the current deformation of the Earth's crust in the central Mediterranean area (Anzidei et al., 1995). The network consists of 50 benchmarks, 34 of which located in
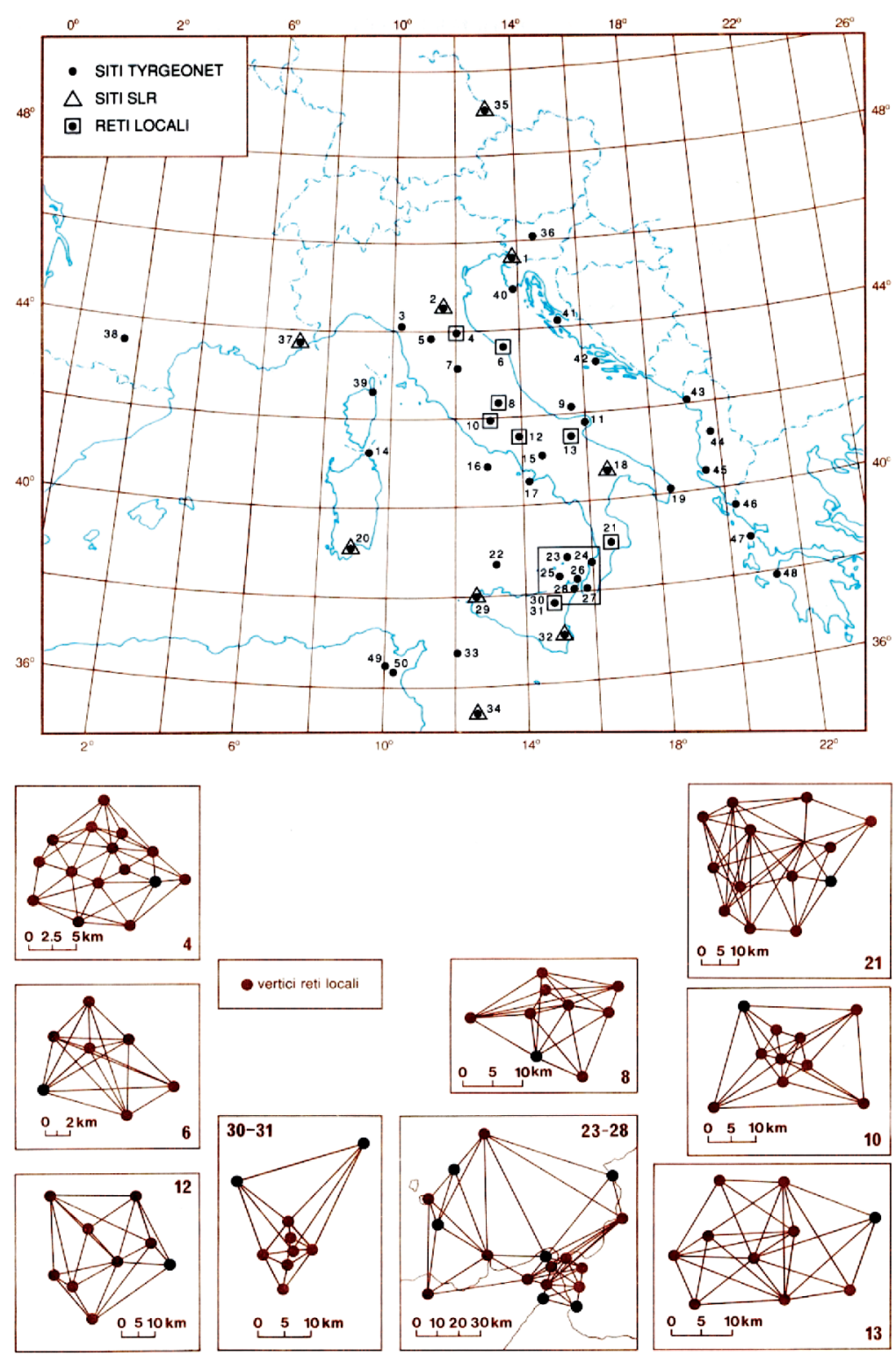

Fig. 1a. The Tyrrhenian Geodetic Network (52 benchmarks) (from Anzidei et al., 1995, modified). 


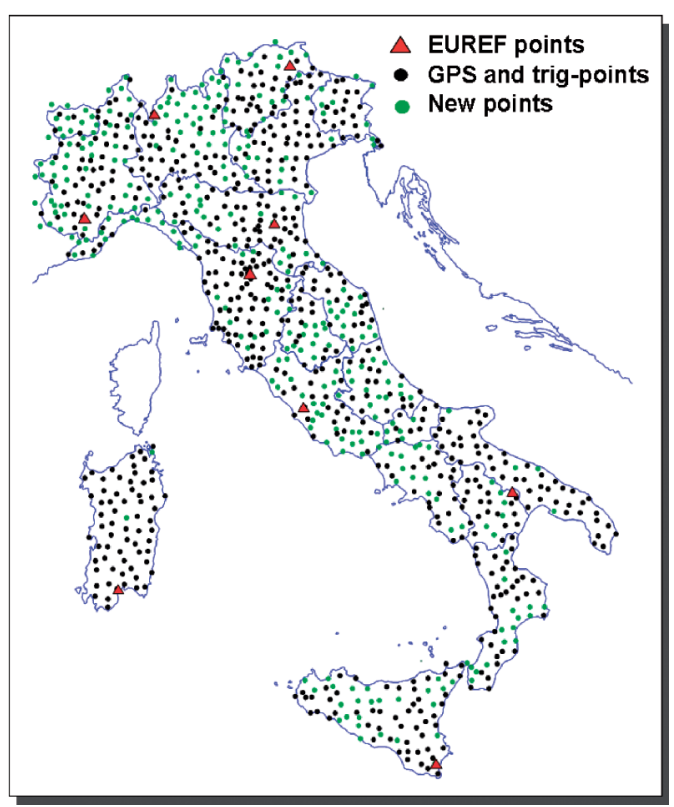

Fig. 1b. The IGM95 (about 1200 benchmarks) (from Surace, 1997, modified).

Italy and 16 in the surrounding countries, partially belonging to the first order IGM network. It includes some local networks, placed in seismic (across the Messina Straits fault, Forlivese, Gargano, etc.) and volcanic areas (Aeolian Islands, Colli Albani, etc.), and it has been measured since 1990 by single and dual frequency GPS receivers.

A densification of TYRGEONET was established in the frame of the GEOdynamic MODeling of the APennines project, funded by the E.C. in the Central-Southern Apennines, with the aim to increase the resolution of the current crustal motion of this seismic region. The GeoModAp network was repeatedly surveyed between 1994 and 2001 and velocity and strain rate fields were estimated for this region (Anzidei et al., 2001; Serpelloni et al., 2002).

Most of the benchmarks of these networks are geodetic pillars often equipped with a force centering plate to permit unambiguous placement of the GPS antenna. Measurements were annually repeated during week-long surveys, with daily sessions of 8-24 hours duration each.
Results from these measurements, published in several papers during the last decade (Anzidei et al., 1996, 1997, 2001; Serpelloni et al., 2005), began delineating the kinematics of the Italian peninsula and the central Mediterranean region (Anzidei et al., 1996).

The IGM95 network, whose measurements were completed in 1995, was planned and set up by the Italian Istituto Geografico Militare to determine a new fundamental network covering the whole country. Since the beginning, the network consisted in more than 1200 benchmarks, partially shared with the Tyrgeonet network, which were occupied during single or repeated measurements sessions of a few hours duration. The aim of this network was to provide a new set of reference coordinates computed into the WGS84 reference system and mainly devoted to cartographic and topographic applications (Surace, 1993; 1997). For this reason, most of the IGM95 sites did not follow restrictive geodetic requirements for geophysical applications in terms of monument quality and particularly, due to the short duration of the data acquisition windows, especially for crustal strain estimation, even if the scientific community gained benefits from this network (D'Agostino et al., 2001).

The final adjustment in one block of the entire network, provided 3-dimensional coordinates with a mean accuracy of $22 \mathrm{~mm}$ and $35 \mathrm{~mm}$ in the horizontal and vertical components, respectively (95\% confidence level) (Surace, 1997).

In 1997 CGPS stations were not yet available in the earthquake area, and the only operational one, was located in peninsular Italy at the Geodetic Space Center of the Italian Space Agency in Matera. Nineteen stations of the IGM95 network were available around the epicentral area of the three main shocks of the Umbria-Marche seismic sequence and were first measured by IGM in March-April 1995 (Anzidei et al., 1998b; 1999; 2000).

Immediately after the Colfiorito earthquakes of September 26, 1997 and the Sellano earthquake of October 14, 1997, two different GPS campaigns were performed, using six GPS TRIMBLE 4000 SSE/SSI dual frequency receivers. The geodetic monuments occupied during these survey consisted of concrete pillars or markers fixed on the ground or on small and sta- 
ble concrete buildings undamaged by the ground shaking (Anzidei et al., 1998a,b). During both campaigns, three receivers were kept fixed at Castiglione del Lago (CAST), Foligno (FOLI), and Colfiorito (COLF), and data were continuously recorded at a 30 second sampling rate. Five roving receivers measured the other sixteen sites during a 4-6 hours time window each day, for at least two survey sessions. The 1997 data were processed by means of the Bernese software (version 4.0) using the precise satellite ephemerides computed at the Centre of Orbit Determination in Europe (CODE), and adopting the standard procedures described by Rothacher et al. (1996), estimating the tropospheric delay and fixing the ambiguities by rounding their real value to the nearest integer one. The 3-dimensional coordinates obtained show a mean accuracy of $10 \mathrm{~mm}$ in the horizontal component (mean value of the semi-axes of the error ellipses) and $20 \mathrm{~mm}$ in the vertical one (both at $95 \%$ confidence level). Site displacements were computed by minimizing the residuals at the GPS stations located at distance greater than 15 $\mathrm{km}$ from the epicenters, assuming that for earthquakes of moment magnitude less than 6.0, coseismic ground deformation is negligible at such distances (Anzidei et al., 1999; Hunstad et al., 1999). The maximum displacement of the stations closest to the epicentral zone, were mainly distributed across and around the earthquake faults, up to $14.0 \pm 1.8 \mathrm{~cm}$ and $24.0 \pm 3.0 \mathrm{~cm}$ along the horizontal and vertical components, respectively, (Anzidei et al., 1998b; Hunstad et al., 1999; Anzidei et al.,1999; Anzidei et al., 2000). Geodetic data were successfully used to identify and model the faults responsible for the main shocks for Colfiorito area and to understand the seismic source mechanics (Hunstad et al., 1999). Moreover, the combination of GPS results with ERS-SAR differential interferograms as well as seismological parameters, allowed the estimation of the geometry and slip distribution on the fault planes (Stramondo et al., 1999; Salvi et al., 2000; Belardinelli et al., 2003) (fig. 2a). Unfortunately, the same actions could not be applied to the Sellano earthquake of October, 14, 1997, due to a lack of available geodetic vertices around the epicentral zone (Salvi et al., 2000) (fig. 2b).

\section{A lesson for the development of new GPS networks}

The inhomogeneous coverage of the IGM95 and Tyrgeonet networks, the quality or type of the benchmarks, the on average short time-window of available observations and the lack of CGPS stations in the earthquake region, prevented us benefitting from optimal geodetic constraints for the geophysical modelling of the causative faults of the Umbria Marche earthquakes, especially in the surroundings of the epicentre of October, 14, 1997, near Sellano, where there was a lack of available GPS benchmarks.

Despite the clear limits of the available GPS data, the location of the geodetic monuments and the re-analysis of the old field data, allowed the geophysical community to benefit from a GPS reference network for the estimation of ground coseismic displacements during the 1997 Umbria Marche earthquakes (Anzidei et al., 1997; 1998b; 1999; 2000; Hunstad et al., 1999; Stramondo et al., 1999; Salvi et al., 2000; Crippa et al., 2006; Dalla Via et al., 2007) (as well as also recently occurred for the 2003 Molise earthquake, as reported in Giuliani et al., 2006).

This fact clarified to the entire Italian geophysics community the need to dispose of new GPS and CGPS networks devoted to geophysical purposes, widely distributed througout the Italian region, with the goal to obtain detailed knowledge of the ongoing crustal strain rates, in order to better constrain the kinematics of the Italian peninsula. At the same time, denser GPS networks were required across known active faults and tectonic structures, equipped with high quality monuments, to have the opportunity to model the deformation processes induced by strong earthquakes at major decoupling zones (Johnson and Wyatt, 1994; Wells and Coppersmith, 1994).

Specifically, the CGPS stations should be able to collect and transmit data in real time, suitable to be processed rapidly (hourly or daily) by data analysis centres. Unfortunately, in 1997 the present technologies applied to GPS receivers were not yet available, especially those concerning continuous data retrieval from 

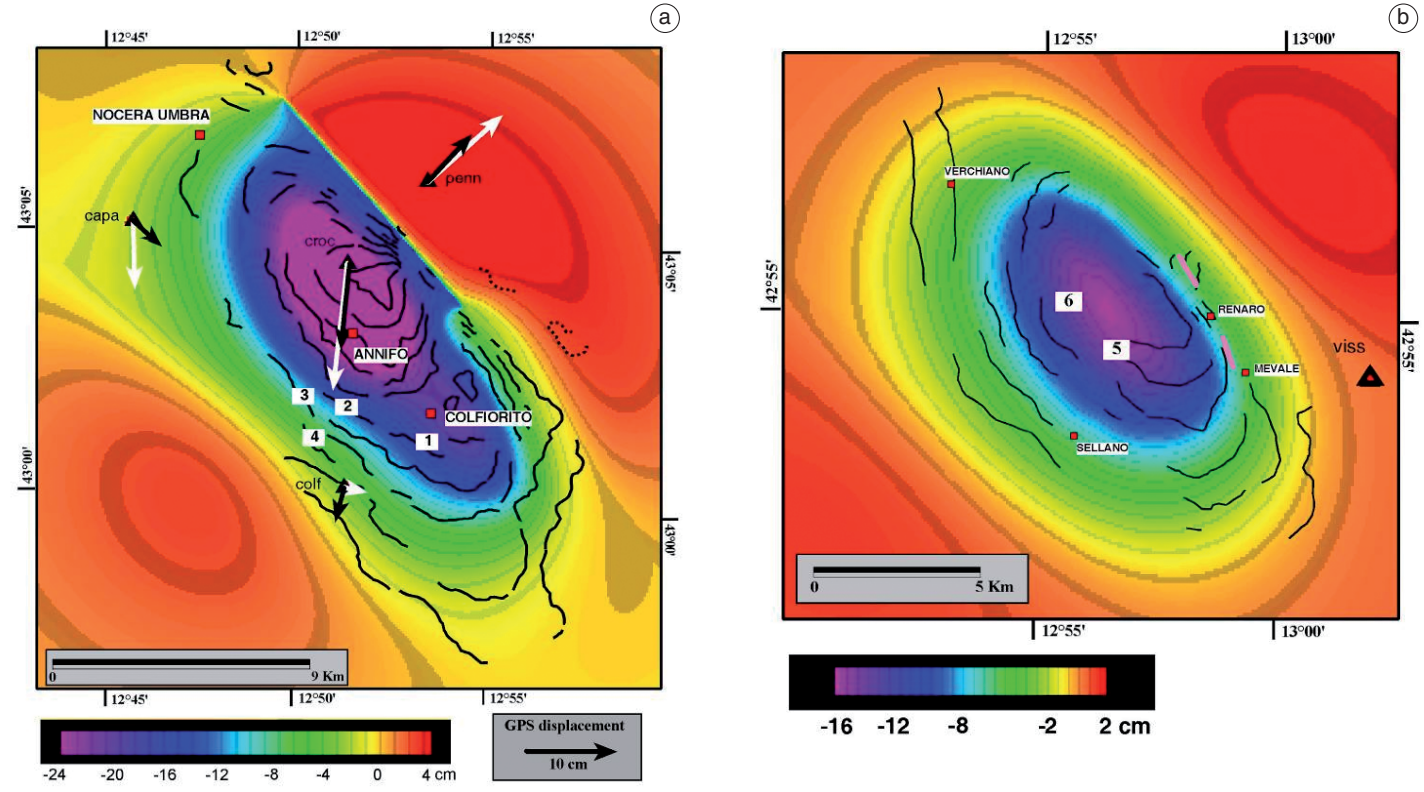

Fig. 2a,b. The distribution of GPS stations and the GPS and SAR modelling from the IGM 95 benchmarks during the 1997 Umbria-Marche earthquakes for the epicentres of September 26, 1997 Colfiorito a) and b) the epicentre of October 14, 1997, Sellano earthquake. The lack of the GPS benchmarks around the epicentre at Sellano is evident and the fortunate positions of the GPS benchmarks across the fault between Colle Croce and Monte Pennino (from Salvi et al., 2000).

remote stations. Only since 2000 the rapid development of GPS space geodesy technique provided a new type of receivers at lower costs, especially planned to be used as CGPS stations, which could be more easily managed and powered through small batteries or solar panels due to a major reduction of their power consumption. These new receivers were also suitable to be used successfully during longer episodic geodetic campaigns. Moreover, they can be controlled by conventional or cellular telephone lines, as well as satellite or internet connections for data retrieval, increasing their range of use dramatically.

The construction of new geodetic networks provided a new source of 3-D geodetic data which began to introduce new constraints on the measurements of the active geological processes occurring in the Mediterranean area (e.g., Battaglia et al., 2004; D'Agostino and Selvaggi, 2004; Goes et al., 2004; D'Agostino et al., 2005; Serpelloni et al., 2005; Serpelloni et al., 2007), focusing on the large scale tectonic aspects (i.e., the motion of major tectonic plates, intra-plate rigidity), but also in more specific areas, through dense and small aperture networks, focusing on local tectonic processes, such as deformation along particular segments of fault zones (e.g., Anzidei et al., 1998a; Anzidei et al., 2005).

With this aim the number of continuous monitoring stations strongly increased in Italy, under national or international research programs and monitoring projects funded by the Italian Space Agency, INGV (under contracts of MIUR and Dipartimento della Protezione Civile) and other institutions (mainly Universities and Regions), following the examples of USA (Zhang et al., 1997) and Japan (Miyazaki et al., 1994) which had been establishing networks consisting of hundreds of stations since 1990 to measure the crustal dynamics and the 
coseismic displacements of their highly seismic regions (Bock et al., 1993; Tsuji et al., 1995 and references therein). Increasingly denser GPS networks, both regional or local, are the mainstay of deformation monitoring, especially over large areas and offer high accuracy and continuous observation, as experimented for the case of the 2004 Sumatra earthquake (Boschi et al., 2006). Dense regional networks, such as the SCIGN network in Southern California (USA) demonstrated the value of such systems. In the meantime, in Italy GPS networks were also developing under specific projects, through the establishment of a large number of additional geodetic vertices in selected areas, such as Southeastern Sicily (Achilli at al., 1995; Bonforte et al., 2002), or the central and southern Apennines (Anzidei et al., 1995; Anzidei et al., 2005).

During the last 10 years, the IGS and other computational centres provided a more precise determination of satellite orbital parameters, through the enlargement of the GPS satellite constellation, and the improvement of the global Continuous CGPS tracking station coverage, resulting in the increasing accuracy of GPS measurements. Moreover, the establishment of regional networks of CGPS stations (e.g., EPNEUREF, ASI, Regal, FredNet networks) increased the number of stations available to tie observations together interferometrically. All these technological developments significantly increased the precision of station position determinations, reducing the noise spectra of the solutions, and allowing for a better resolution of the coordinate changes detection, even in the vertical component. This is fundamental in areas characterized by low deformation rates, where an accurate estimate of crustal deformation parameters mainly requires the use of CGPS stations.

In Italy, several CGPS stations began to operate after 1997, and especially after 2000 , were managed by different agencies, private companies and national scientific institutions (Sansò and De Lacy, 2000). Unfortunately, a significant number of these stations do not follow the minimum requirements needed for geophysical applications (antenna/receiver features and geodetic monument quality). For this reason, new CGPS and GPS stations have been planned by
INGV, with the specific goal to provide a geodetic infrastructure able to provide high quality GPS data. In recent years the number of CGPS and GPS stations suitable for geophysical applications has rapidly increased, particularly in the frame of INGV activities, mainly supported by the Dipartimento della Protezione Civile, MIUR and ASI. From this perspective, automatic facilities to handle the CGPS data archiving and data processing have been developed and applied (Serpelloni et al., 2006b).

\subsection{The new GPS networks}

The development and the accuracy of the GPS technique, imposed to project and realize new GPS monuments following restrictive requirements needed for geophysical purposes (benchmarks placed in stable outcrops, concrete pillars or stable buildings, planned to improve antenna position repeatability during surveys). Besides the IGM95 network, more than 300 benchmarks are currently available belonging to sub-regional or local INGV GPS networks, distributed in selected seismic areas of the Italian region, mainly across the Apennines and the Messina Straits (fig. 3a).

In the following, besides the large development of the IGM95 network (fig. 3b) mainly devoted to topographic applications, three major new GPS networks, CAgeoNet, RETREAT and Capo Vaticano, together with the INGV Rete INtegrata GPS (RING) CGPS network, are briefly described as follows. These new GPS networks, designed after the experience gained during the 1997 Umbria-Marche seismic crisis, are located across some of the most seismic areas of Italy and they have been repeatedly measured during recent years. These networks which provided valuable data for the ongoing geodynamic and seismotectonic studies, have driven a new road to plan and build GPS networks in seismically active faulted areas. The reduced distance between the vertices and the average grid at a few $\mathrm{km}$, can increase the resolution of the geodetic strain and velocity fields as well as its temporal and spatial variability (Anzidei et al., 2005) across faults and seismogenic structures known from historical 

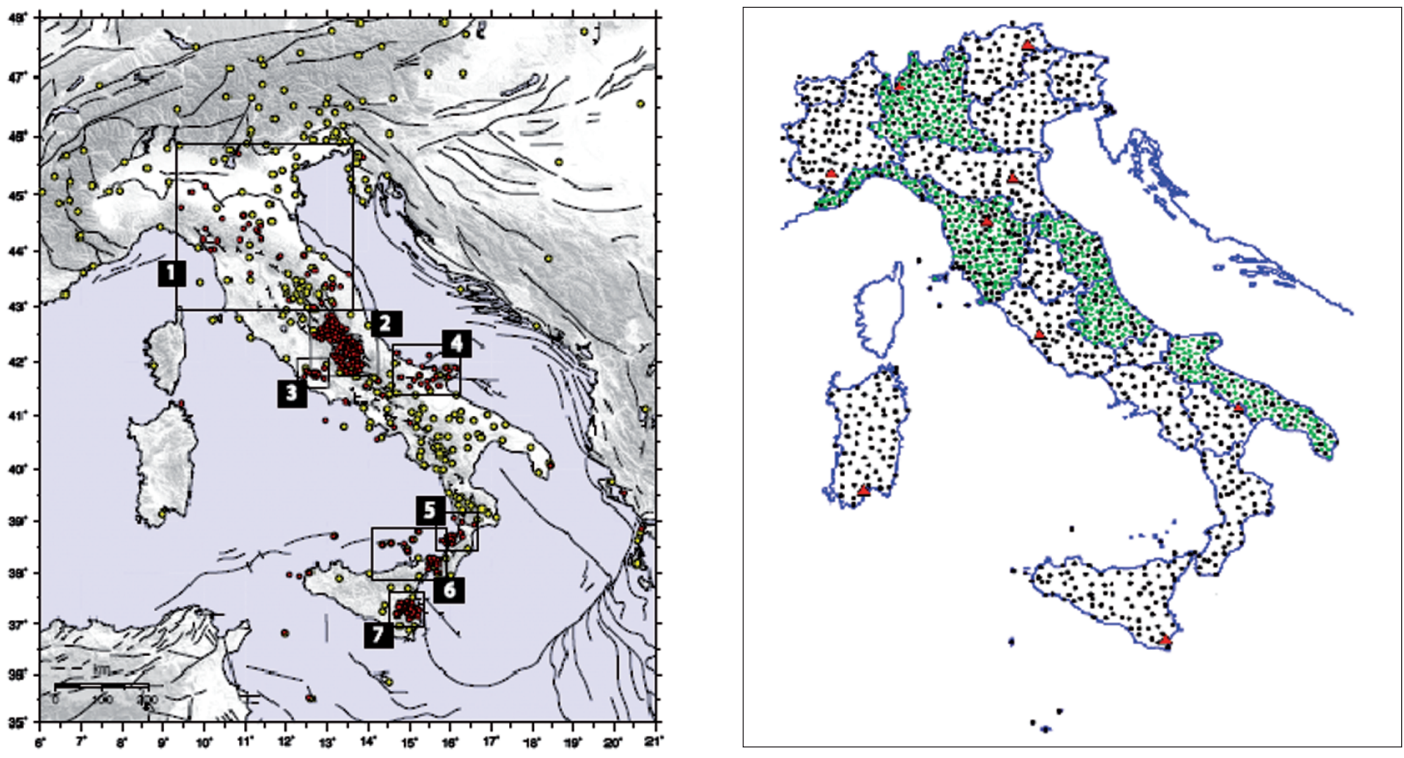

Fig. 3a,b. a) The GPS (red) and CGPS geophysical networks at 2007. After 1997 have been established and included in the analysis about new 300 GPS benchmarks in the following areas: 1) RETREAT, 2) CA-GeoNet, 3) Colli Albani, 4) Gargano, 5) Capo Vaticano, 6) Messina Straits and Arco Calabro, 7) South-Eastern Sicily; b) The IGM95 network at September 2007. About 4000 benchmarks (2000 of the I order and 2000 of the II order).

sources and geological constraints (Valensise and Pantosti, 2001b).

CAGeoNet - The Central Apennines Geodetic Network (CA-GeoNet), was established in the time span 1999-2001, under the umbrella of the ASI projects. It consists of 125 GPS stations equipped with 3-D monuments, distributed with an average grid at 3-5 km (Anzidei et al., 2005) across the main seismogenic structures of the central Apennines (fig. 3a). Siting was performed taking into account the geological and structural features of the region. Most of the GPS stations are located across the Plioquaternary basins and the main active faults, inferred from geological and seismological data (Valensise and Pantosti, 2001).

Retreat - The RETREAT GPS Network has been realized in the framework of the REtreating TRench Extension and Accretion Tectonics (RETREAT) project, funded by the National Science Foundation (USA) in the frame of the Continental Dynamics Program, in cooperation with several American and European Universities and re- search centres (http//earth.geology.yale.edu/RETREAT/). The aim of the project is to understand the evolution of the convergence and rapid uplift of the northern Apennines, studying the relationships between the surface geological processes and the deep dynamics of the Earth's mantle, to obtain new constraints on the kinematics and seismotectonics of the northern Italian region. The new network consists in 22 stations often equipped with 3-D monuments (fig. $3 a)$. Three of them have become continuous since 2004.

Capo Vaticano - The Capo Vaticano GPS network was established in 2002 in the framework of a INGV multidisciplinary project funded by CNR-Agenzia 2000, carried out in cooperation with other Italian universities and institutions (Anzidei et al., 2006). The goal of the network is to provide the current horizontal and vertical deformation rates across the main seismogenic faults in the area of the September 8, 1905, Ms= 7.0 earthquake (Boschi et al., 1995), and give new data on the relative sea level 
changes along the coast of the Capo Vaticano promontory. The network, which consists in 13 monuments 3-D type distributed with an average grid at $3-5 \mathrm{~km}$, has been measured since 2002 (fig. 3a). Recently, it has been extended with another 20 additional benchmarks partially overlapping with a previous terrestrial geodetic network (Pingue and Guerra, 1989), recently reoccupied and extended.

\subsection{The new CGPS networks}

In the last decade the number of CGPS sites operating in the Italian region and in the Central Mediterranean region, has significantly increased. This action was led by EUREF initiative as a partner of IGS for the European region, while in Italy the largest developments have mainly been produced since 1995 by ASI and after 2000 by INGV, under the umbrella of the Italian Department of Civil Protection. Densifications exist in some specific areas of geophysical interest, as for example in Friuli Venezia Giulia, where the Frednet (FRiuli REgional Deformation NETwork, http://www.crs.inogs.it/frednet/) is maintained by the OGS or in Tuscany where the Universities of Bologna and Siena, supported by Regione Toscana, have set up a network of 9 permanent GPS stations around the principal tectonic troughs in Tuscany, which have been the sites of the most intense earthquakes in the region (Cenni et al., 2008). Some additional currently operating stations are maintained by university departments, administrative agencies, or by professional companies. Besides these geophysical networks, some Regional administrations have also developed their own CGPS networks, mainly designed for topographic or navigation applications.

RING network - In 1999, the INGV, began to set up a permanent GPS network in Italy with the goal to detect the crustal deformation for geodynamics (Anzidei et al., 2004). The RING (Rete Integrata Nazionale GPS) network started at the beginning with 6 stations (Anzidei et al., 2004) and grew up rapidly all over the Italian region, thanks to specific funding provided by the Department of Civil Protection and the Ministry for Universities and Research (MIUR)
(Selvaggi et al., 2006) (figs. 4 and 5). Most of the stations are co-located with seismic stations. The GPS antenna is connected to the pillar by means of two different devices: the INGV-3D antenna mount (Anzidei and Esposito, 2003) and the SCIGN antenna mount (http://jacinto.ucsd.edu/gpsmon/adaptor_design/intro.html). Raw data are transferred daily to a local server and archived. The Observatory of Grottaminarda currently maintains the RING as well as the data archiving, quality check and distribution (www.gm.ingv.it).

The RING network is still increasing and nowadays consists in about 120 continuously monitoring stations remotely controlled mainly by satellite systems, with an average grid at about $50 \mathrm{~km}$ or less (Selvaggi et al., 2006). It is the most powerful CGPS geophysical network active in Italy and is partially densified by the networks managed by the Italian Space Agency (Vespe et al., 2000), and the Universities of Bologna and Siena in Tuscany region (Cenni et al., 2008).

Together with increasing in the GPS networks, new development of the GPS data analysis software and procedures was performed to fit the new large amount of data coming from the CGPS stations and GPS networks. New powerful processors were used together with suitable data storage systems to archive the resulting daily, weekly, monthly and annual solutions of the GPS networks. Currently data from hundreds of stations belonging to RING and to other national or European regional CGPS networks are collected and processed to produce position time-series (Serpelloni et al., 2006b).

\section{Recent results}

After the first pioneering geodetic results at global and regional scale for the Mediterranean region (Smith et al., 1994) or in Italy (Anzidei et al., 1996; 1998a), in recent years new results have been published (Anzidei et al., 2001; Anzidei et al., 2005; Oldow et al., 2002; Hollenstein et al., 2003; Caporali et al., 2003, Serpelloni et al., 2002; 2005; 2006; 2007; D'Agostino and Selvaggi, 2004; D'Agostino et al., 2005 among others), providing new con- 


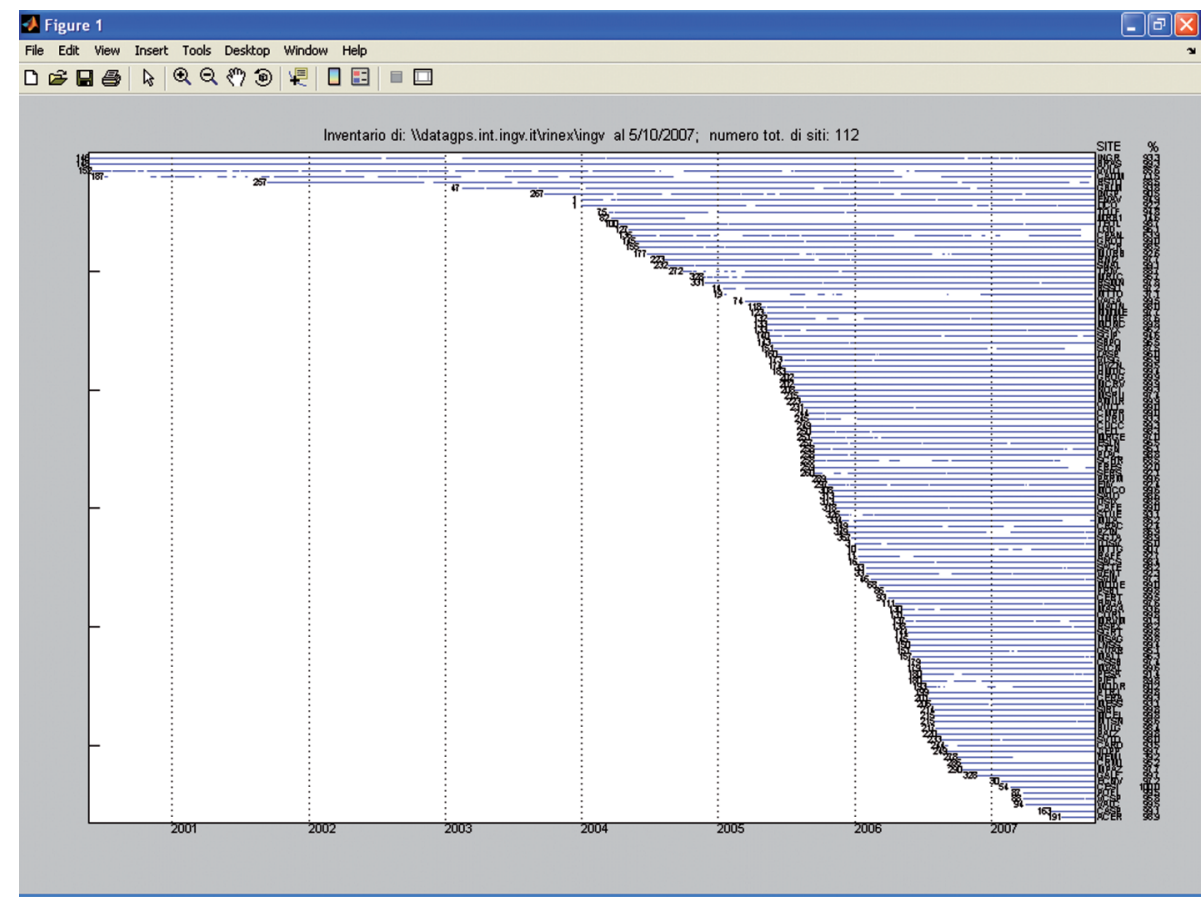

Fig. 4. Temporal evolution and data inventory for the single stations of the RING network. A sharp increase of the CGPS stations starts since 2004 (courtesy of Dr. R. Devoti).

straints on the active deformation of the Italian peninsula in the frame of the Mediterranean geodynamics. The complex kinematics and tectonic pattern due to the collision of the EurasiaAfrica plates and the interaction of several minor crustal blocks (i.e., ADRIA) began to be partially revealed thanks to the high number of available GPS and CGPS stations and in some cases to the high density of the networks.

After the Umbria-Marche earthquakes of 1997, the increase in geodetic monitoring through GPS and CGPS networks, at local and regional scale, yielded new insights on the kinematics of the Italian peninsula as well as new constraints to the geological and seismological evolution of this seismically active region (Serpelloni et al., 2005; Serpelloni et al., 2007; D'Agostino and Selvaggi, 2004; D'Agostino et al., 2006; Anzidei et al., 2005; Hunstad et al., 2003; Battaglia et al., 2004). Figure 6 shows the last velocity field obtained by the combination of GPS and CGPS stations in the time span 1991-2007. GPS data show that the lineament of seismogenic faults, which are striking about parallel to the chain axis, appears to play a fundamental role for the major kinematics boundaries, in separating two different velocity domains: an Adriatic one, with NE- to NNE-ward motion trends, and a Tyrrhenian one, with NWto NNW-ward motion trends.

The regional $\sim \mathrm{NE}-\mathrm{SW}$ extension of the Apennines was detected through GPS data, in agreement with seismological and geological evidence (fig. 7). The rates of extension along the southern and central sectors of the chain are estimated at $\sim 1.8$ and $\sim 2.5 \mathrm{~mm} / \mathrm{yr}$, respectively, and deformation appears to be mainly confined to a relatively narrow belt, within which the largest part of the seismic moment release is observed and most of the seismogenic faults are located. In the Southern Apennines, across the Irpinia region, NE-SW extension is occurring at 


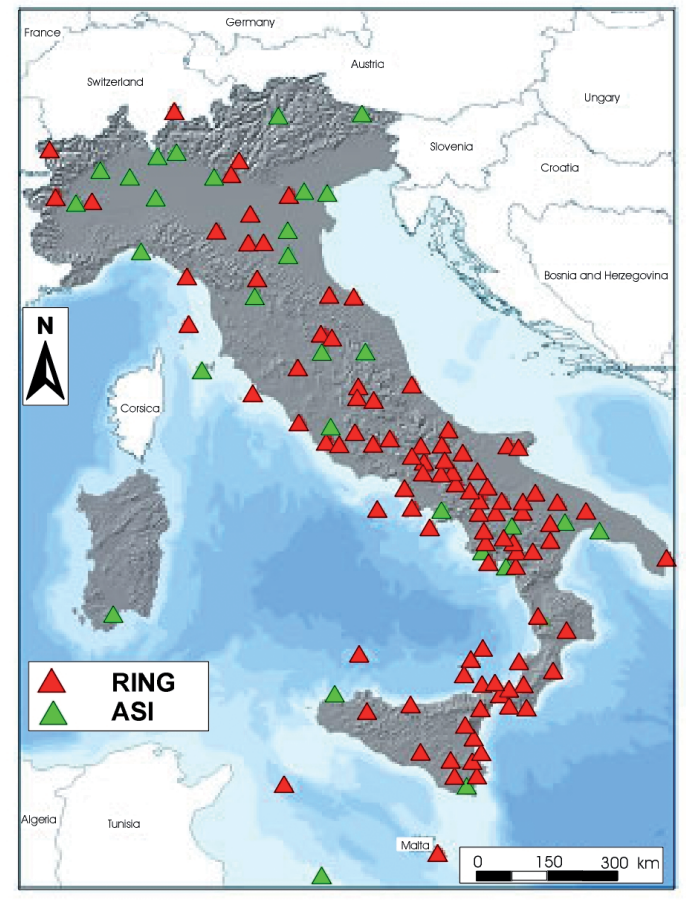

Fig. 5. The Ring Network at 2007 (in green ASI stations) (courtesy of Dr. G. Selvaggi, modified).

a rate of about $2.3 \mathrm{~mm} / \mathrm{yr}$. The area of transition between the Southern and Central Apennine arcs (i.e. Southern Latium and Molise regions), instead, displays a more complicated deformation pattern, where right-lateral strike slip motion active along E-W trending faults, at a rate up to $2.8 \mathrm{~mm} / \mathrm{yr}$, could explain the high local strains observed. In this area, between Latium, Umbria, Marche and Abrutii regions, the densifications provided by the GPS CAGeoNet network, with a grid at 3-5 km, disclosed an active aseismic NE-SW prevailing extension normal to the chain, even if this region experienced destructive earthquakes in the past (Anzidei et al., 2005). Moreover, local complexities have been evidenced, likely related to deep gravitational movements or faults, still under investigation. So far this interseismic deformation describes the regional and purely elastic deformation field of this area while its extensional behaviour is in agreement with the distribution and trend of the main seismogenic sources reported in Valensise and Pantosti (2001b). The latter could play a major role in the observed deformations and in the kinematics of Italian peninsula.

In the Northern Apennines, regional extension at $\sim 3.3 \mathrm{~mm} / \mathrm{yr}$ appears to be mainly confined to its inner sector, while small SW-NE to $\mathrm{N}-\mathrm{S}$ shortening is present in its outer sector. The two velocity profiles across the Northern Apennines show that most of the regional extension observed is currently taking up its northern-western sector (Northern Tuscany), while moving toward the Umbria-Marche region, extension is more localized in a narrow band. They also show that the outer sector of the chain displays smaller deformation rates, and indications of active shortening (at rates below the $1 \mathrm{~mm} / \mathrm{yr}$ level) are observed only in the outer Northern Apennines, and mainly in the Emilia-Romagna Region.

While there is no evidence of active NW-SE back-arc spreading currently active in the Tyrrhenian Basin, a NW-SE extension at more than $2 \mathrm{~mm} / \mathrm{yr}$ is active in Calabria; nevertheless, this value must be considered preliminary, given the still poor geometry of the available geodetic network. The deformation rates observed in the rest of the peri-Adriatic region (i.e. Southern Alps and Dinarides) are related to the counter-clockwise rotation of the Adriatic microplate with respect to Eurasia, displaying values of SW-NE shortening along the Dinaric front ranging between 2 and $3.3 \mathrm{~mm} / \mathrm{yr}$, and rates of N-S to SW-NE shortening in the Eastern Alpine between 1 and $2 \mathrm{~mm} / \mathrm{yr}$.

In the Central Mediterranean, D'Agostino and Selvaggi (2004) from GPS and CGPS data, focused on the crustal deformation along the Eurasia-Nubia plate boundary in Calabria and Sicily, disclosing two distinct crustal domains, characterized by different motions and styles of deformation. Significant Eurasia $(\sim 3 \mathrm{~mm} / \mathrm{yr}$ to $\mathrm{NNE}$ ) and Nubia-fixed ( $5 \mathrm{~mm} / \mathrm{yr}$ to ESE) residual velocities in Calabria were found, suggesting the presence of an intermediate crustal block which can be interpreted as a forearc sliver or as an independent Ionian block. The first hypothesis indicates a still active subduction in the Ionian wedge, although no evidence was found for active back arc spreading in the Tyrrhenian Sea. It is relevant that up to $3 \mathrm{~mm} / \mathrm{yr}$ 


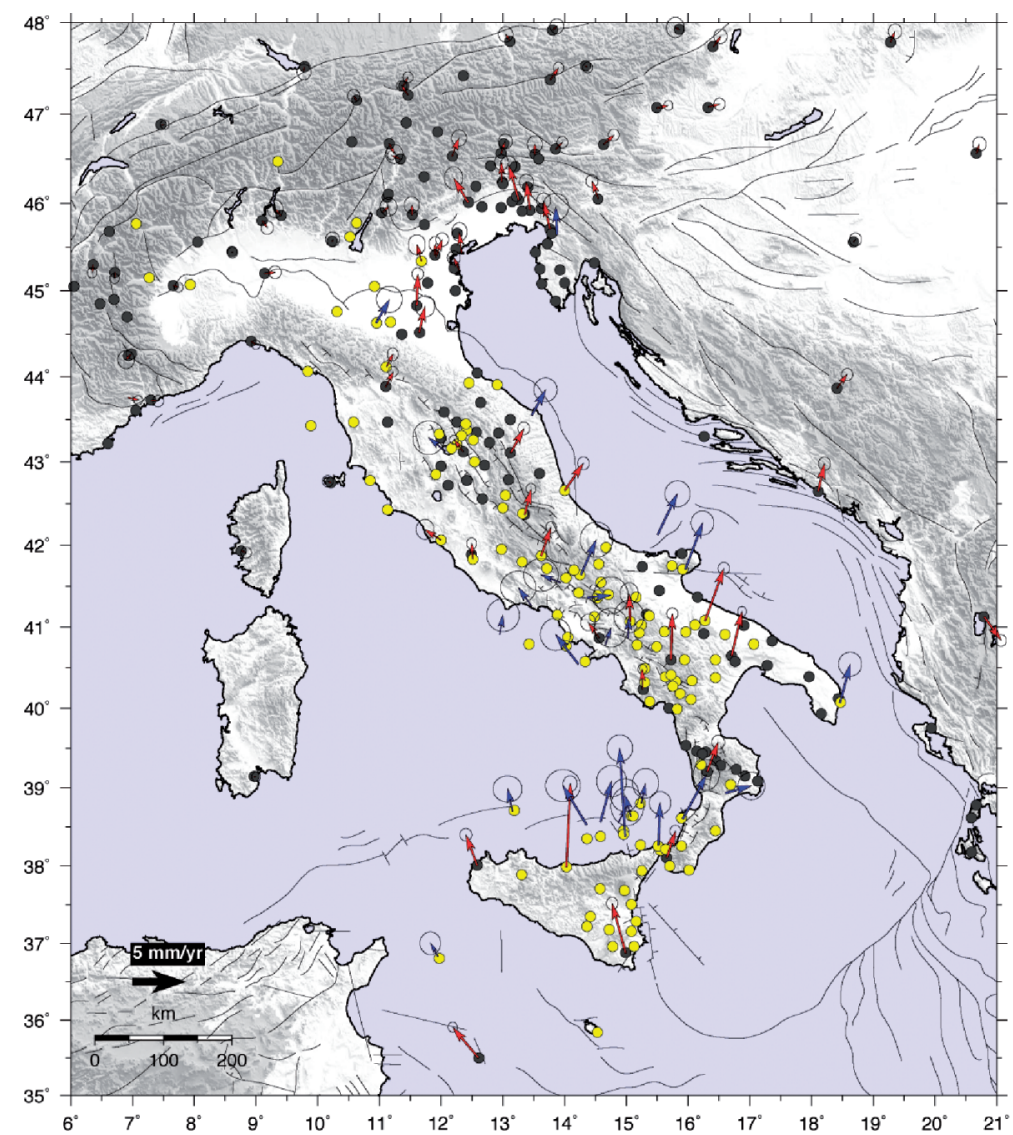

Fig. 6. Velocity field in Italy and surrounding regions from GPS (blue) and CGPS (red) networks.

$(\sim 80 \%)$ of this estimated relative motion between Sicily and the Calabrian Arc may be taken up in the Messina Straits, locus of the great $1908, \mathrm{M}_{\mathrm{W}}=7.1$ earthquake.

Serpelloni et al. (2007), studying the kinematics Western Mediterranean, revealed a more complex fragmentation of the Nubian and Eurasian plate boundaries than previously proposed. The analysis suggests that the SicilianPelagian domain is moving independently from Nubia, according to the presence of a right-lateral and extensional decoupling zone corresponding to the Tunisia-Libya and Strait of Sicily deformation zone. Despite the space variability of active tectonic regimes, plate conver- gence still governs most of the seismotectonic and kinematic setting up to the central Aeolian region. Along Calabria and the Apennines the contribution of the subducted Ionian oceanic lithosphere and the occurrence of microplates (i.e. Adria) appear to substantially modify both tectonics and kinematics. Across the Gibraltar Arc and the Tyrrhenian-Calabria domain data induce the hypothesis that slab rollback in these regions is mostly slowed down or stopped.

\section{Conclusions}

The Umbria-Marche earthquakes marked a 
change in the evolution of the GPS networks in Italy. On the one hand, new GPS networks have been installed in selected areas using high accuracy 3-D geodetic benchmarks distributed with average grid up to $3-5 \mathrm{~km}$. On the other, the CGPS network developed thanks to the new technologies provided by the GPS manufacturers as well as the fast data transmission by satellite or internet together with the new powerful computer processors and hardware used to analyse and archive data (Serpelloni et al., 2006). The gap with respect to other countries characterized by high seismic hazard, has now been filled and nowadays continuous and not permanent GPS networks useful for geophysics studies are active in the Italian region following the examples of the USA (Zhang et al., 1997) and Japan (Miyazaki et al., 1994), which have established hundreds of stations since 1990 to measure the crustal dynamics and the coseismic displacements of their highly seismic regions (Bock et al., 1993; Tsuji et al., 1995 and references therein).

These new GPS networks are continuously adding new constraints on the kinematics and current deformation of the Italian peninsula, as well as allowing more detailed studies of the seismogenic structures during different phases of the seismic cycle. Moreover, the combination of GPS and seismic observations together with DiSAR data (Massonnet et al., 1993; Massonnet and Feigl, 1998), will help to determine the size, location and extent of co-seismic deformations, better than the case of the 1997

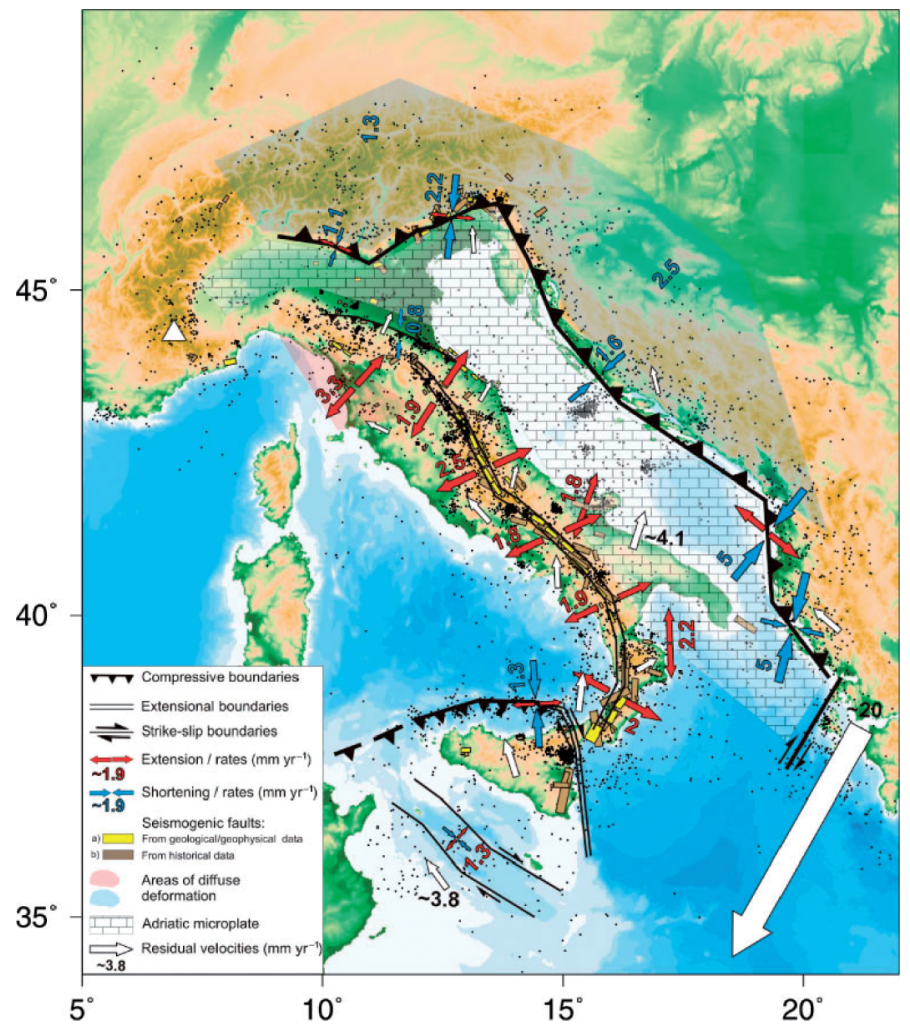

Fig. 7. Current geodetic strain field of the Italian region from GPS and CGPS data (from Serpelloni et al., 2006a). 
Umbria- Marche earthquakes (Hunstad et al., 1998; Anzidei et al., 1999; Stramondo et al., 1999; Salvi et al., 2000).

\section{Acknowledgements}

This work was partially funded by the Agenzia Spaziale Italiana (ASI-ARS contract), the Ministero dell'Università e della Ricerca Scientifica e Tecnologica and the Dipartimento della Protezione Civile. We thank Prof. Enzo Boschi and Dr. Calvino Gasparini who encouraged this work since the beginning, and ASI, which have made available high-quality CGPS data since 1990 .

\section{REFERENCES}

Achilli, V., M. Anzidei, P. Baldi., F. Broccio and R. VeLARDITA (1995): The Southeastern Sicily GPS Network, Annali di Geofisica, Vol. 2.

Amato, A., R. Azzara, C. Chiarabba, G.B. Cimini, M. Cocco, M. Di Bona, L. Margheriti, S. Mazza, F. Mele, G. Selvaggi, A. Basili, E. Boschi, F. Courboulex, A. Deschamps, S. Gaffet, G. Bittarelli, L. Chiaraluce, D. Piccinini and M. Ripepe (1998): The 1997 Umbria-Marche, central Italy earthquake sequence: a first look at main shocks and aftershocks, Geophys. Res. Lett., 25 (15), 2861-2864.

ANDERSON, H.J. and J.A. JACKSON (1987): Active tectonics of the Adriatic region., Geophys. J. R. Astron. Soc., 91, 937-983.

Anzidei, M., P. Baldi, G. Casula, F. Riguzzi and L. SuRACE (1995): La rete Tyrgeonet, Supplemento al Bollettino di geodesia a scienze affini, vol. LIV, n. 2.

Anzidei, M., P. Baldi, G. Casula, F. Riguzzi and A. ZANuTTA (1995): Geomodap Project GPS network, Pubblicazioni dell'Istituto Nazionale di Geofisica, 570, Roma.

Anzidei, M., P. Baldi, G. Casula, M. Crespi and F. RiguZZI (1996): Repeated GPS Surveys across the Ionian Sea: evidence of crustal deformations, Geophysical Journal International, 127, 257-267.

Anzidei, M., P. Baldi, S. Del Mese, A. Galvani, C. Guidi, I. Hunstad and A. Pesci (1997): Studio preliminare del campo di spostamento e di deformazione prodotto dal terremoto di Colfiorito dall'analisi di dati geodetici. Pubblicazioni dell'Istituto Nazionale di Geofisica, 593, 38-41.

Anzidei, M., P. Baldi, C. Bonini, G. Casula, S. Gandolfi and F. RiguZZI (1998a): GPS surveys across the Messina Straits (Southern Italy) and comparison with terrestrial geodetic data, Journal of Geodynamics, $\mathbf{2 5}$ (2), 85-97.

Anzidei, M., P. Baldi, A. Coticchia, S. Del Mese, A. Galvani, I. Hunstad, A. Pesci, L. Surace and A.
ZANUTTA, (1998b): Utilizzo della rete GPS IGM95 per lo studio delle deformazioni cosismiche dei terremoti umbro marchigiani del 26 settembre 1997, Bollettino di Geodesia e Scienze Affini, 3, 325-335.

Anzidei, M., P. Baldi, A. Galvani, A. Pesci, I. Hunstad and E. Boschi (1999): Coseismic displacement of the 27th september 1997 Umbria - Marche (Italy) earthquakes detected by GPS: campaigns and data, Annali di Geofisica, 42 (4), 597-607.

Anzidei, M., P. Baldi, G. Casula, A. Galvani, A. Pesci and ZanutTa A. (2000): Spostamenti rilevati alle stazioni GPS della rete IGM95 poste nell' area dell'Appennino umbro-marchigiano dopo gli eventi sismici del settembre-ottobre 1997, Bollettino di Geodesia e Scienze Affini, LIX (3), 281-290.

Anzidei, M., P. Baldi, G. Casula, A. Galvani, E. MantoVAni, A. Pesci, F. RiguzZi and E. Serpelloni (2001): Insights on present-day crustal motion in the Central Mediterranean area from GPS surveys, Geophysical Journal International, 146, 98-110.

ANZIDEI, M. and A. Esposito (2003): Linee guida per la identificazione di siti idonei alla realizzazione di stazioni GPS permanenti e non permanenti, Rapporti tecnici INGV, 18.

Anzidei, M., G. Casula, A. Galvani, F. Riguzzi, G. Pietrantonio, A. Massucci, S. Del Mese, F. Loddo, A. Pesci and A. EsPosito (2004): Le prime stazioni GPS permanenti INGV-CNT per il monitoraggio delle deformazioni crostali dell'area italiana, Quaderni di Geofisica, 39.

Anzidei, M., P. Baldi, A. Pesci, A. Esposito, A. Galvani, F. Loddo, P. CRistofoletti, A. Massucci and S. Del Mese (2005): Geodetic deformation across the Central Apennines from GPS data in the time span 1999-2003, Annals of Geophysics, 48 (2), 259-272.

Anzidei, M., A. Esposito, F. Antonioli, A. Benini, A. TerTULLIANI and C. DEL GRANDE (2006): I movimenti verticali nell'area di Briatico: evidenze da indicatori archeologici marittimi nell'area del terremoto del 1905. Regione Calabria, Università della Calabria, Deputazione di Storia Patria per la Calabria "8 settembre 1905 - Terremoto in Calabria”, edited by I. GuERra e A. BAVAGLio.

Battaglia, M., M.H. Murray, E. Serpelloni and R. Burgmann (2004): The Adriatic region: an independent microplate within the Africa-Eurasia collision zone, Geophys. Res. Lett., 31, L09605, doi: 10.1029/2004GL019723.

Belardinelli, M.E., L. SAndri and P. Baldi (2003): The major event of the Umbria-Marche (Italy) sequence: what could we learn from DInDAR and GPS data?, Geophys. J. Int., 153, 242-252.

Bock, Y., D.C. Agnew, P. FAnG, J.F. GENRICH, B.H. HAGER, A.T. Herring, K.W. Hudnut, R.W. King, S. Larsen, J.B. MinSTER, K. STARK, S. WDOWINSKI and F. WyatT (1993): Detection of crustal deformation from the Landers earthquake sequenze using continuous geodetic measurements, Nature, 361, 337-340

Bonforte, A., M. Anzidei, G. Puglisi, M. Mattia, O. Campisi, G. Casula, A. Galvani, A. Pesci, G. Puglisi, S. GRESTA and P. BALDI (2002): GPS surveys in the foreland-foredeep tectonic system of southeastern Sicily: first results (2002), Annals of Geophysics, 45 (5), 673-682. 
Boschi, E., E. Guidoboni, G. Ferrari, G. Valensise and P. GASPERINI (1995): Catalogo dei forti terremoti in Italia dal 461 a.C. al 1980, ING SGA, Bologna.

Boschi, E., E. Casarotti, R. Devoti, D. Melini, A. PierSAnti, G. Pietrantonio and Riguzzi F., (2006): Coseismic deformation induced by the Sumatra, earthquake, 42 (1-3), 52-62.

CAporali, A., S. Martin and M. Massironi (2003): Average strain rate in the Italian crust inferred from a permanent GPS network - II. Strain rate versus seismicity and structural geology, Geoph. Jou. Int., 155, 254-268.

Capuano, P., A. Zollo, A. Emolo, S. Marcucci and G. MilanA (2000): Rupture mechanism and source parameters of Umbria- Marche mainshocks from strong motion data, Journ. of Seism., 4, 479-499.

Cattaneo, M., P. Augliera, G. De Luca, A. Gorini, A. Govoni, S. Marcucci, A. Michelini, G. Monachesi, D. Spallarossa, L. Trojani and XGUMS (2000): The 1997 Umbria-Marche (Italy) earthquake sequence: analysis of the data recorded by the local and temporary networks, Journ. of Seism., 4, 479-499.

Cenni, N., P. Baldi, E. Mantovani, M. Ferrini, M. Viti, V. D'Intinosante, D. Babbucci and D. Albarello (2008): Short-term (geodetic) and long-term (geological ) deformatin pattern in the Northern Apennines, Boll. Soc. Geol. It., 127 (1), 93-104.

Chiarabba, C., L. Jovane and R. Di Stefano (2005): A new view of Italian seismicity using 20 years of instrumental recordings, Tectonophysics, 395, 251-268.

Crippa, B., M. Crosetto, E. Biescas, C. Troise, F. Pingue and G. De Natale (2006): An advanced slip model for the Umbria-Marche earthquake sequence: coseismic displacements observed by SAR interferometry and model inversion, Geophys. J. Int., 164, 36-45.

Dalla Via, G., B. Crippa, E. M. Toraldo Serra, G. GiacoMUZZI and R. SABADINI (2007), Exploitation of high-density DInSAR data points of the Umbria-Marche (Italy) 1997 seismic sequence for fault characteristics, Geophys. Res. Lett., 34, L17301, doi: 10.1029/2007GL030718.

D'Agostino, N., R. Giuliani, M. Mattone and L. Bonci (2001): Active crustal extension in the central Apennines (Italy) inferred from GPS measurements in the interval 1994-1999, Geoph. Res. Lett., 28, 10, 21212124.

D'Agostino, N., D. Cheloni, S. Mantenuto, G. Selvaggi, A. Michelini and D. Zuliani (2005): Strain accumulation in the southern Alps (NE Italy) and deformation at the northeastern boundary of Adria observed by CGPS measurements, Geoph. Res. Lett., 32, L19306, doi: 10.1029/2005GL024266

D'Agostino, N. and G. Selvaggi (2004): Crustal motion along the Eurasia-Nubia plate boundary in the Calabrian Arc and Sicily and active extension in the Messina Straits from GPS measurements, Jou. of Geoph. Res., 109, B11402, doi: 10.1029/2004JB002998.

DeMets, C., R.G. Gordon, D.F. Argus and S. Stein (1994): Effect of recent revisions to the geomagnetic reversal time scale on estimates of current plate motions, Geophys. Res. Lett., 21, 2191-2194.

Dercourt, J., L.E. Ricou and B. VRIELYNCK (eds) (1993): Atlas Tethys Palaeonvironmental Maps, pp. 307, 14 maps, 1 pl, Gauthiers-Villars, Paris.

Deschamps, A., et al., (2000): Spatio-temporal distribution of seismic activity during the Umbria-Marche crisis, 1997, Journ. of Seism., 4, 479-499

Dewey, J.F., M.L. Helman, E. Turco, D.H.W. Hutton and S.D. KNOTT (1989): Kinematics of the Western Mediterranean, in Alpine Tectonics, edited by M.P. Coward, D. Dietrich and R.G. PARK, Geol. Soc. London, Spec. Publ., 45, 265-283.

Ekström, E., A. Morelli, E. Boschi and A.M. DziewonsKI (1998): Moment tensor analysis of the Central Italy earthquake sequence of September-October 1997, Geophys. Res. Lett., 25, 1971-1974.

Faccenna, C., C. Piromallo, A. Crespo-Blanc, L. JoLIVET and F. RosSETTI (2004): Lateral slab deformation and the origin of the western Mediterranean arcs, Tectonics, 23, TC1012, doi: 10.1029/2002TC001488

Gasperini, P. and G. Ferrari (2000). Deriving numerical estimates from descriptive information: the computation of earthquake parameters, Annali di Geofisica, 43, 729-746.

Giuliani, R., M. Anzidei, L. Bonci, S. Calcaterra, N. D’Agostino, M. Mattone, G. Pietrantonio, F. RiguZZI and G. SelvagGi, (2006): Co-seismic displacements associated to the Molise (Southern Italy) earthquake sequence of October - November 2002 inferred from GPS measurements, Tectonophysics, 432, 21-35.

Goes, S., D. Giardini, S. Jenny, K. Hollenstein, H.G. Khale and A. Geiger (2004): A recent tectonic reorganization in the south-central Mediterranean, Earth. Planet. Scie. Lett., 226, 335-345.

JoHnson, H.O. and F.K. WyATT, (1994): Geodetic network design for fault mechanics studies, Manuscr. Geod., 19, 309-323.

Hollenstein, C., H.G.Kahle, A. Geiger, S. Jenny, S. GoEs and D. GIARDINI (2003): New GPS constraints on the Africa-Eurasia boundary zone in southern Italy. Geoph. Res. Lett., vol. 30, n. 18, 1935, http://geomatica.como.polimi.it/gps/articoli/asi.pdf.

Hunstad, I. and P. ENGLAND (1999): An upper bound on the rate of strain in Central Apennines, Italy, from triangulation measurements between 1869 and 1963, Earth and Pla. Sci. Lett., 169, 261-267.

Hunstad, I., M. Anzidei, M. Cocco, P. Baldi, A. Galvani and A. PESCI (1999): Modelling coseismic displacements during the 1997 Umbria-Marche earthquake (Central Italy), Geophysical Journal International, 139, 283-295.

Hunstad, I., G. Selvaggi, N. D'Agostino, P. England, P. Clarke and M. PierozZI (2003): Geodetic strain in peninsular Italy between 1875 and 2001, Geoph. Res. Lett., 30, no. 4, 1181.

MaLinverno, A. and W.B.F. Ryan (1986): Extension in the Tyrrhenian Sea and shortening in the Apennines as result of arc migration driven by sinking in the lithosphere, Tectonics, 5, 227-245.

Massonnet, D., M. Rossi, C. Carmona, F. Adragna, G. Peltzer, K. Feigl and T. Rabaute (1993): The displacement field of the Landers earthquake mapped by radar interferometry, Nature, 364, 138-142.

Massonnet, D. and K. Feigl (1998): Radar interferometry and its applications to the changes in the Earth's surface, Reviews of Geophysics, 36, 441-500.

MiyazaKi, S., H. Tsuji, Y. Hatanaka, Y. Abe, A. YoshimuRa, K. Kamada,K. Kobayashi, H. Morishita and Y. 
IIMURA (1994): Establishment of the nationwide GPS array (Grapes) and its initial results on the crustal deformation of Japan, Bullettin of the Geographical Survey Inst., 42.

Montone, P. and M.T. Mariucci (1999): Active stress along the NE external margin of the Apennines: the Ferrara arc, northern Italy, J. Geodyn., 28, 251-265.

IGOS-geohazard Theme Report 2003 (2003): IGOS an Integrated Global Observing Strategy for the monitoring of our Environment from Earth and Space, http://dup.esrin.esa.it/igos-geohazards, pp. 56.

Oldow, J.S., L. Ferranti, D.S. Lewis, J.K. CampBell, B. D'Argenio, R. Catalano, G. Pappone, L. Carmignani, P. CONTI and L.V. AIKEN (2002): Active fragmentation of Adria based on Global Positioning System velocities and regional seismicity, Geology, 30, 779-782.

PAtacca E., R. SARTORI and P. ScAndone (1990): Tyrrhenian basin and Apenninic arcs. Kinematic relations since late Tortonian times, Mem. Soc. Geol. It., 45, 425-451.

Pingue, F. and I. Guerra (1989): Geodetic monitoring of crustal deformations in the Catanzaro trough, Calabria, Southern Italy, Boll. Geod. e Sc. Aff., 2, 145-163.

Piromallo, C. and A. Morelli (2003): P-wave tomography of the mantle under the Alpine-Mediterranean area, $J$. Geophys. Res., 108 (B2), doi: 10.1029/2002JB001757.

PINO, N.A. and S. MAZZA (2000): The Umbria-Marche (Central Italy) earthquakes: relation between rupture directivity and sequence evolution for the $\mathrm{Mw}>5$ shocks, Journ. of Seism., 4, 479-499.

Pondrelli S., A. Morelli and E. Boschi (1995): Seismic deformation in the Mediterranean area estimated by moment tensor summation, Geophys. J. Int., 122, 938-952.

Pondrelli, S., A. Morelli, G. Ekström, S. Mazza, E. Boschi and A.M. DzIEwONSKI (2002): EuropeanMediterranean regional Centroid Moment Tensors Catalog: 1997-2000, Phys. Earth Planet. Int., 130, 71-101.

Rothacher, M. and L. Mervart (1996): Bernese GPS Software Version 4.0, (Astronomical Institute University of Berne).

Rothacher, M. and L. Mervart (2000): Bernese GPS Software Version 4.0, (University of Berne, Switzerland).

Salvi S., S. Stramondo, M. Cocco, E. Sansosti, I. Hunstad, M. Anzidei, P. Briole, P. Baldi, M. Tesauro, E. Lanari, F. Doumaz, A. Galvani and A. Pesci (2000): Modelling coseismic displacement resulting from sar interferometry and gps measurements during the 1997 Umbria-Marche seismic sequence, Journal of Seismology, 4, 479-499.

SAnsò, F. and M.C. DE LACY (2000): Uno studio sulle diverse applicazioni del GPS e sul futuro sviluppo della rete di stazioni permanenti GPS sul territorio italiano orientato alla creazione di un servizio geodetico nazionale (available on line at http://geomatica.como.polimi.it(gs/articoli/asi.pdf).

SelvaGgi, G. (1998): Spatial distribution of horizontal seismic strani in the Apennines from historical earthquakes, Ann. Geofis., 41 (2), 241-251.

Selvaggi, G. and A. AmAto (1992): Subcrustal earthquakes in the Northern Apennines from historical earthquakes, Ann. of Geoph., 41, 241-251.

Selvaggi, G., M. Mattia, A. Avallone, N. D’ Agostino, L. Abruzzese, M. Anzidei, M. Cantarero, V. Cardinale, A. Castagnozzi, G. Casula, G. Cecere, R.
Cogliano, F. Crisculoli, C. D’Ambrosio, E. D'Anastasio, P. De Martino, S. Del Mese, G. De Luca, R. Devoti, L. Falco, V. Flammia, A. Galvani, L. Giovani, I. Hunstad, A. Massucci, F. Minichello, A. Memmolo, F. Migliari, R. Moschillo, F. Obrizzo, M. Palano, G. Pietrantonio, M. Pignone, M. PulvirenTI, M. Rossi, F. Riguzzi, E. SERPELloni, U. TAMmaro and L. ZARRILLI (2006): La Rete Integrata Nazionale GPS (RING) dell' INGV: una infrastruttura aperta per la ricerca scientifica, Atti della X Conferenza Nazionale dell'ASITA, (Bolzano 14-17 novembre 2006).

Serpelloni E., M. Anzidei, P. Baldi, G. Casula, A. GalVANI, A. PESCI and F. RiguZZI (2002): Combination of permanent and non-permanent GPS networks for the evaluation of the strain-rate field in the central Mediterranean area, Bollettino di Geofisica Teorica ed Applicata, 43 (3-4), 195-219.

Serpelloni E., M. Anzidei, P. Baldi, G. Casula and A. GALVANI (2005): Crustal velocity and strain-rate fields in Italy and surrounding regions: new results from the analysis of permanent and non-permanent GPS networks, Geophysical Journal International, 161 (3), 861-880, doi: 10.1111/j.1365-246X.2005.02618.

Serpelloni, E., M. Anzidei, P. Baldi, G. Casula and A. GALVANI (2006a): GPS measurements of active strains across the Apennines., Ann. Geoph., 49, n. 1, 319-329.

Serpelloni, E. , G. Casula, A. Galvani, M. Anzidei and P. BALDI (2006b): Data analysis of Permanent GPS networks in Italy and surrounding region: application of a distributed processing approach, Ann. Geophys., 49 (45), 897-928.

Serpelloni, E., G. Vannucci, S. Pondrelli, A. Argnani, G. CAsula, M. Anzidei, P. BALdi and P. Gasperini (2007): Kinematics of the Western Africa - Eurasia Plate Boundary From Focal Mechanisms and GPS Data., Geophys. J. Int., doi: 10.1111/j.1365-246X.2007.03367.x.

Smith, D.E., R. Koenkiewicz, R.S. Nerem, P.J. Dunn, M.H. Torrence, J.W. Robbins, S.M. Klosko, R.G. Williamson and E.C. PAVlis (1994): Contemporary global horizontal motion, Geophys. Jou. Int., 119, 511520 .

Stramondo, S., M. Tesauro, P. Briole, E. Sansosti, S. SAlvi, R. LAnari, M. Anzidei, P. Baldi, G. Fornaro, A. Avallone M.F. Buongiorno, G. Franceschetti and E. Boschi (1999): The September 26,1997 Central Italy earthquakes: coseismic surface displacement detected by sar interferometry and GPS, and fault modeling., Geophysical Research Letters, 26 (7), 883-886.

Surace, L. (1993): Il progetto IGM95, Boll. Geod. Sci. Aff., 3, 220-230.

SurACE, L. (1997): La nuova rete geodetica nazionale IGM95: risultati e prospettive di utilizzazione, Boll. Geod. Sci. Aff., 3, 335-377.

Tosi, P., A. Tertulliani, V. De Rubeis and C. Gasparini (1999): Preliminary results of a macroseismic survey of the Colfiorito sequence (Central Italy), Phys. Chem. Earth., 24, 477-481.

Tsuji, H., Y. Hatanaka, T. Sagiva and M. Hashimoto (1995): Coseismic crustal deformation from the 1994 Hokkaido-Toho-Oki earthquake monitored by a nationwide continuous GPS array in Japan, Geoph. Res. Lett., 22 (13), 1669-1672.

VAlensise, G. and D. PAntosti (2001a): The investigation 
of potential earthquake sources in peninsular Italy: a review, J. Seism., 5, 287-306.

VAlensise, G. and D. Pantosti (2001b): Database of potential sources for earthquakes larger than $\mathrm{M}=5.5$ in Italy, Ann. Geophys., 44 (supp. to n. 4), 180 (with CD-Rom).

VANNUCCI, G. and P. GASPERINI (2004): The new release of the database of Earthquake Mechanisms of the Mediterranean Area (EMMA Version 2), Annals of Geophysics, 1 (supp. to n. 47), 307-334.

Vespe, F., G. Bianco, M. Fermi, C. Ferraro, A. Nardi and C. ScIARRETTA (2000): The Italian GPS fiducial network: services and products, Jou. of Geodyn., 30, 327-336.
WeLls, D. L. and K.J. CopPERSMith (1994): New empirical relationships among Magnitude, rupture length, rupture width, rupture area, and surface displacement, Bull. Seism. Soc. of Am., 84, (4), 974-1002.

Westaway, R., (1990): Present-day kinematics of the plate boundary zone between Africa and Europe, from the Azores to the Aegean, Earth Plan. Sci. Lett., 96, 393-406.

Zhang, J., Y. Bock, H. Johnson, P. Fang, S. Williams, J. GENRICH, S. WDOWINSKI and J. BEHR (1997): Southern California Permanent GPS Geodetic array: error analysis of daily positions estimates and site velocities, Jou. Geoph. Res., 102, n. B8, 18035-18055. 